Engineering and Design: Most Central Knowledge in Architecture and Engineering Jobs

\author{
Panagiotis G. Asteris, Ph.D., M.ASCE and \\ George K. Neofotistos, Ph.D.
}

ABSTRACT: Rapid changes in the worldwide engineering enterprise are creating a compelling rationale to rethink how future generations of engineers should be educated. In this paper, we identify the most central knowledge in engineering and architecture jobs by analyzing the characteristics of the weighted jobs-knowledge network for all occupations in the Architecture and Engineering job family of the O*NET (Occupational Information Network) system. Engineering and design constitute the most central knowledge. Strengthening education in the identified central knowledge themes can lead to better transport of knowledge to engineering jobs to address the challenges of the 21 st century.

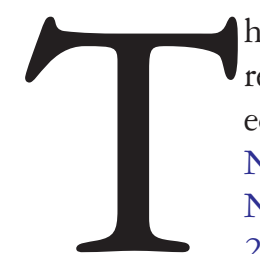

here has been considerable discussion recently about improving engineering education ("Special Report" 2006; National Science Foundation 1995; National Academy of Sciences et al. 2010; Spinks et al. 2006; Engineers Australia 1996; National Academy of Engineering 2004; Kirschenman and Brenner 2010, 2011). This discussion stems from a widespread belief that skills and education should be improved to satisfy the demands of jobs in the current economy (Handel 2003; Bresnahan et al. 2002). A significant dimension of the rapidly emerging global economy is the "green" economy-that is, economic activity related to reducing the use of fossil fuels, decreasing pollution and greenhouse gas emissions, increasing the efficiency of energy use, recycling materials, and developing and adopting renewable sources of energy.
Considerable debate has revolved around envisioning the future and responding to these global challenges (Liao 2008 and references therein).

To study the changing world of work, the National Center for O*NET Development (O*NET is the Occupational Information Network, an online service developed for the U.S. Department of Labor; see O*NET n.d.) investigated the impact of green economy activities and technologies on occupational requirements and the development of new and emerging (N\&E) occupations (Dierdorff et al. 2009). Results of the $\mathrm{O} * \mathrm{NET}$ research led to the identification of green economic sectors, green increased demand occupations, green enhanced skills occupations, and green N\&E occupations (National Center for O*NET Development 2009). The engineering job family (Architecture and Engineering) comprises more than one-fifth (13 occupations) of the green 
enhanced skills occupations and almost one-third (28 occupations) of the total green N\&E occupations (Neofotistos and Asteris 2010).

To contribute to the development of an efficient green jobs engineering pipeline that is flexible enough to support diverse career aspirations and a broad range of concerns, we sought to identify the most central knowledge in the existing Architecture and Engineering job family in the O*NET database. Our approach was inspired by recent advances in network theory suggesting that transport in networks can be

Table 1. List of 0 *NET Knowledge Categories

\begin{tabular}{ll}
\hline No. & \multicolumn{1}{c}{ Category } \\
\hline 1 & Administration and Management \\
2 & Biology \\
3 & Building and Construction \\
4 & Chemistry \\
5 & Clerical \\
6 & Communications and Media \\
7 & Computers and Electronics \\
8 & Customer and Personal Service \\
9 & Design \\
10 & Economics and Accounting \\
11 & Education and Training \\
12 & Engineering and Technology \\
13 & English Language \\
14 & Fine Arts \\
15 & Food Production \\
16 & Foreign Language \\
17 & Geography \\
18 & History and Archeology \\
19 & Law and Government \\
20 & Mathematics \\
21 & Mechanical \\
22 & Medicine and Dentistry \\
23 & Personnel and Human Resources \\
24 & Philosophy and Theology \\
25 & Physics \\
26 & Production and Processing \\
27 & Psychology \\
28 & Public Safety and Security \\
29 & Sales and Marketing \\
30 & Sociology and Anthropology \\
31 & Telecommunications \\
32 & Therapy and Counseling \\
33 & Transportation \\
\hline & \\
&
\end{tabular}

Table 2. List of Jobs in the 0*NET Architecture and Engineering Job Family

\begin{tabular}{|c|c|}
\hline No. & Job \\
\hline 1 & $\begin{array}{l}\text { Aerospace Engineering and Operations } \\
\text { Technicians }\end{array}$ \\
\hline 2 & Aerospace Engineers \\
\hline 3 & Agricultural Engineers \\
\hline 4 & Architects, except Landscape and Naval \\
\hline 5 & Architectural Drafters \\
\hline 6 & Biomedical Engineers \\
\hline 7 & Cartographers and Photogrammetrists \\
\hline 8 & Chemical Engineers \\
\hline 9 & Civil Drafters \\
\hline 10 & Civil Engineering Technicians \\
\hline 11 & Civil Engineers \\
\hline 12 & Computer Hardware Engineers \\
\hline 13 & Electrical Drafters \\
\hline 14 & Electrical Engineering Technicians \\
\hline 15 & Electrical Engineers \\
\hline 16 & Electro-Mechanical Technicians \\
\hline 17 & Electronic Drafters \\
\hline 18 & Electronics Engineering Technicians \\
\hline 19 & $\begin{array}{l}\text { Electronics Engineers, Except } \\
\text { Computer }\end{array}$ \\
\hline 20 & $\begin{array}{l}\text { Environmental Engineering } \\
\text { Technicians }\end{array}$ \\
\hline 21 & Environmental Engineers \\
\hline 22 & $\begin{array}{l}\text { Fire-Prevention and Protection } \\
\text { Engineers }\end{array}$ \\
\hline 23 & Industrial Engineering Technicians \\
\hline 24 & Industrial Engineers \\
\hline 25 & Industrial Safety and Health Engineers \\
\hline 26 & Landscape Architects \\
\hline 27 & Mapping Technicians \\
\hline 28 & Marine Architects \\
\hline 29 & Marine Engineers \\
\hline 30 & Materials Engineers \\
\hline 31 & Mechanical Drafters \\
\hline 32 & Mechanical Engineering Technicians \\
\hline 33 & Mechanical Engineers \\
\hline 34 & $\begin{array}{l}\text { Mining and Geological Engineers, } \\
\text { including Mining Safety Engineers }\end{array}$ \\
\hline 35 & Nuclear Engineers \\
\hline 36 & Petroleum Engineers \\
\hline 37 & Product Safety Engineers \\
\hline 38 & Surveying Technicians \\
\hline 39 & Surveyors \\
\hline
\end{tabular}


significantly enhanced by improving the highcentrality nodes (Wu et al. 2006). Thus, strengthening the central knowledge can lead to better transport of knowledge to the engineering and architecture jobs in the contemporary world.

\section{O*NET DATABASE}

O*NET is an online service developed for (but not by) the U.S. Department of Labor (as the successor to the better-known Dictionary of Occupational Titles) containing information on U.S. occupations

Table 3. Weights of the Links between Knowledge and Selected Jobs Comprising the O*NET Architecture and Engineering Job Family

\begin{tabular}{|c|c|c|c|c|c|}
\hline \multirow[b]{2}{*}{ Knowledge } & \multicolumn{5}{|c|}{ Job Weight } \\
\hline & Architects & $\begin{array}{c}\text { Civil } \\
\text { engineers }\end{array}$ & $\begin{array}{l}\text { Electrical } \\
\text { engineers }\end{array}$ & $\begin{array}{l}\text { Industrial } \\
\text { engineers }\end{array}$ & $\begin{array}{c}\text { Mechanical } \\
\text { engineers }\end{array}$ \\
\hline \multirow{2}{*}{\multicolumn{6}{|c|}{ Management }} \\
\hline & & & & & \\
\hline Biology & 18 & 28 & 10 & 18 & 2 \\
\hline Building and Construction & 97 & 94 & 21 & 29 & 25 \\
\hline Chemistry & 23 & 53 & 43 & 28 & 33 \\
\hline Clerical & 50 & 42 & 38 & 56 & 21 \\
\hline Communications and Media & 44 & 36 & 26 & 23 & 27 \\
\hline Computers and Electronics & 65 & 56 & 86 & 64 & 53 \\
\hline Customer and Personal Service & 62 & 60 & 48 & 50 & 43 \\
\hline Design & 94 & 95 & 73 & 62 & 75 \\
\hline Economics and Accounting & 43 & 44 & 20 & 50 & 13 \\
\hline Education and Training & 42 & 42 & 38 & 57 & 29 \\
\hline Engineering and Technology & 72 & 98 & 98 & 88 & 88 \\
\hline English Language & 67 & 78 & 76 & 57 & 55 \\
\hline Fine Arts & 38 & 5 & 5 & 9 & 0 \\
\hline Food Production & 2 & 7 & 1 & 9 & 4 \\
\hline Foreign Language & 4 & 14 & 9 & 16 & 1 \\
\hline Geography & 33 & 47 & 16 & 17 & 5 \\
\hline History and Archeology & 32 & 18 & 5 & 9 & 0 \\
\hline Law and Government & 57 & 56 & 15 & 34 & 15 \\
\hline Mathematics & 66 & 88 & 78 & 84 & 72 \\
\hline Mechanical & 49 & 39 & 42 & 65 & 78 \\
\hline Medicine and Dentistry & 4 & 6 & 6 & 8 & 2 \\
\hline Personnel and Human & 34 & 48 & 20 & 38 & 12 \\
\hline \multicolumn{6}{|l|}{ Resources } \\
\hline Philosophy and Theology & 14 & 13 & 6 & 8 & 2 \\
\hline Physics & 40 & 73 & 70 & 43 & 50 \\
\hline Production and Processing & 38 & 31 & 53 & 86 & 73 \\
\hline Psychology & 30 & 26 & 41 & 34 & 11 \\
\hline Public Safety and Security & 59 & 60 & 33 & 36 & 33 \\
\hline Sales and Marketing & 50 & 41 & 28 & 23 & 32 \\
\hline Sociology and Anthropology & 19 & 11 & 19 & 27 & 3 \\
\hline Telecommunications & 35 & 25 & 54 & 26 & 7 \\
\hline Therapy and Counseling & 3 & 8 & 9 & 18 & 1 \\
\hline Transportation & 18 & 68 & 22 & 34 & 13 \\
\hline
\end{tabular}


that correspond to the Labor Department's Standard Occupational Classification (SOC). The O*NET database contains information on standardized and occupation-specific descriptors and is continually updated via a survey of a broad range of workers from each occupation. The O*NET_SOC 2006 taxonomy included 949 occupational titles, 812 of which represent data-level occupations.

In June 2009, the release of the O*NET 14.0 database (O*NET_SOC 2009) updated the taxonomy to include 1,102 occupational titles, 965 of which represent O*NET data-level occupations. Regarding the impact of the green economy, O*NET created three general occupational categories, each describing different consequences of green economy activities and technologies for occupational performance (Dierdorff et al. 2009; National Center for O*NET Development 2009):

1. Green increased demand occupations (64 occupations)—Employment demand has increased for an existing occupation (but this impact does not entail significant changes in the work and worker requirements of the occupation - the work context may change, but the tasks themselves do not);

2. Green enhanced skills occupations (60 occupations) - The work and worker requirements of an existing O*NET-SOC occupation have changed significantly (but the impact may or may not result in an increase in employment demand for the occupation - the essential purposes of the occupation remain the same, but tasks, skills, knowledge, and external elements, such as credentials, have been altered); and

3. Green new and emerging occupations (91 occupations) - A need for unique work and worker requirements has been created, resulting in the generation of a new occupation in the O*NET taxonomy (this new occupation could be entirely novel or born of an existing occupation).

\section{Methodological Approach and Results}

We undertook to identify the most central knowledge in the Architecture and Engineering job family of the $\mathrm{O} *$ NET database, in which each job is characterized by a weight in each one of the 33 knowledge categories (Table 1). The Architecture and Engineering job family consists of 39 jobs (Table 2); Table 3 presents the weights of selected engineering jobs.

We applied methods of network analysis to reveal the most central knowledge by identifying the maximum spanning tree (MST) in the jobs-knowledge
Table 4. Ranking of the Most Central Knowledge Domains in the Jobs-Knowledge Network of the $0 *$ NET Architecture and Engineering Job Family

\begin{tabular}{lc}
\hline $\begin{array}{l}\text { Architecture and Engineering } \\
\text { occupations }\end{array}$ & $\begin{array}{c}\text { Degree } \\
\text { centrality }\end{array}$ \\
\hline Engineering and Technology & 20 \\
Design & 9 \\
Computers and Electronics & 6 \\
Mathematics & 4 \\
Production and Processing & 2 \\
Law and Government & 2 \\
Geography & 2 \\
\hline
\end{tabular}

Note: Ranks are in descending order by the total sum of nonzero maximum spanning tree degree centralities.

network and ranking the centrality of its nodes. We treated the network as a monopartite network (however, the results remain the same by treating the network as a bipartite weighted network; this part of our work will be presented in a companion paper). In particular, we ascertained the most central knowledge by identifying the MST in the network. The MST is the tree connecting all nodes with the maximum total weight and dominates transport in weighted networks. The MST is obtained from the weighted network using Prim's algorithm.

In large, complex networks, not all nodes are equivalent (Wu et al. 2006; Braunstein et al. 2007). The degree centrality ranking addresses the question, Which is the most important or central node in this network? The simplest of centrality measures is degree centrality, also called simply degree. The degree of a node in a network is the number of links attached to it. We view the jobs-knowledge network in terms of its transport properties-that is, the ease with which knowledge is linked to engineering jobs. Links with greater weights can be interpreted as more important ("wider") roads in connecting the nodes, and nodes with higher centrality are more important in spanning the network. From this perspective, transport in the aforementioned weighted network is dominated by the MST.

Once we identified the MST, we ranked the degree centrality of its nodes; the results are presented in Table 4. The most central knowledge categories are Engineering and Technology, Design, Computers and Electronics, Mathematics, Production and Processing, Law and Government, and Geography. Indeed, considerable effort is currently being directed 
at improving these central engineering knowledge areas (Kirschenman and Brenner 2011; ASCE 2008).

\section{Conclusion}

This paper describes the results of our applied network analysis of the most central knowledge in the Architecture and Engineering job family in the O*NET database. The two areas of most central knowledge we identified-(1) Engineering and Technology and (2) Design - validate efforts such as those of the ASCE Body of Knowledge (BOK) committees to change the way the civil engineering curriculum is presented. They also suggest use of a series of project-based design courses as a central core theme (Kirschenman and Brenner 2010, 2011) for the 5-year education period proposed in the BOK-2 document (ASCE 2008). These efforts should be strongly considered as extending beyond the boundaries of the civil engineering field. Our findings contribute to the ongoing discourse on how future generations of scientists, engineers, managers, and other professionals should be educated and constitute a first step toward the development of a more efficient engineering pipeline leading to a better integrated educational framework that is flexible enough to support diverse career aspirations and a broad range of concerns.

\section{REFERENCES}

ASCE. (2008). Civil engineering body of knowledge for the 21st century, 2nd Ed., Reston, VA. 〈http:// apps.asce.org/professional/educ (Sep. 3, 2011).

Braunstein, L. A., et al. (2007). "Optimal path and minimal spanning trees in random weighted networks." Int. J. Bifurcation Chaos Appl. Sci. Eng., 17(7), 2215-2255.

Bresnahan, T. F., Brynjolfsson, E., and Hitt, L. M. (2002). "Information technology, workplace organization, and the demand for skilled labour: Firm-level evidence." Q. J. Econ., 117, 339-376.

Dierdorff, E. C., Norton, J. J., Drewes, D. W., Kroustalis, C. M., Rivkin, D., and Lewis, P. (2009). "Greening of the world of work: Implications for O*NET-SOC and new and emerging occupations." National Center for O*NET Development, Raleigh, NC. 〈http://www.onetcenter .org/reports/Green.html (Sep. 3, 2011).

Engineers Australia. (1996). Changing the culture: Engineering education into the future, Barton, ACT Australia.

Handel, M. J. (2003). "Skills mismatch in the labour market." Аnnu. Rev. Sociol., 29, 135-165.
Kirschenman, M. D., and Brenner, B. (2010). "Education for civil engineering: A profession of practice." Leadership Manage. Eng., 10(1), 54-56.

Kirschenman, M. D., and Brenner, B. (2011). "Civil engineering design as the central theme in civil engineering education curriculum." Leadership Manage. Eng., 11(1), 69-71.

Liao, S. C. (2008). "Envisioning and creating the future in response to global climate change." Leadership Manage. Eng., 8(3), 100-101.

National Academy of Engineering. (2004). "The engineer of 2020: Visions of engineering in the new century." Washington, DC. 〈http://www.nap .edu/catalog/10999.html (Sep. 3, 2011).

National Academy of Sciences, National Academy of Engineering, and Institute of Medicine. (2010). "Rising above the gathering storm: Employing America for a brighter economic future." Washington, DC. 〈http://www.nap.edu/catalog/ 11463.html〉 (Sep. 3, 2011).

National Center for O*NET Development. (2009). "New and emerging occupations of the 21st century: Updating the O*NET-SOC taxonomy report.” Raleigh, NC. 〈http://www.onetcenter.org/ reports/UpdatingTaxonomy2009.html $\rangle$ (Sep. 3, 2011).

National Science Foundation. (1995). "Restructuring engineering education: A focus on change." Washington, DC. 〈http://www.nsf.gov/pubs/ stis1995/nsf9565/nsf9565.txt) (Sep. 3, 2011).

Neofotistos, G., and Asteris, P. (2010). "Green jobs of the 21st century: New and emerging occupations (as appear in the O*NET_SOC 2009 updated taxonomy)." Rep. TR-04-01-2010, University of Crete, Greece.

O*NET (Occupational Information Network). (n.d.) "O*NET resource center." $\langle$ http://www.onetcenter .org/overview.html〉 (Sep. 3, 2011).

"Special report: The research agenda for the new discipline of engineering education." (2006). J. Eng. Edu., 95(4), 259-261.

Spinks, N., Silburn, N., and Birchall, D. (2006). "Educating engineers for the 21st century: The industry view." Henley Management College and Royal Academy of Engineering, Oxfordshire, England. 〈http://www.raeng.org.uk/news/releases/ henley/pdf/henley_report.pdf $\rangle$ (Sep. 3, 2011).

Wu, Z., Braunstein, L. A., Havlin, S., and Stanley, H. E. (2006). "Transport in weighted networks: Partition into superhighways and roads." Phys. Rev. Lett., 96(14), 148702. 
Panagiotis G. Asteris is assistant professor and director of the Computational Mechanics Laboratory, School of Pedagogical \& Technological Education, Athens, Greece. He received his B.S., M.S., and Ph.D. degrees in civil engineering from the National Technical University of Athens (NTUA) and joined the Institute of Structural Analysis and Seismic Research, NTUA, as a research associate. He can be contacted at pasteris@otenet.gr.
George K. Neofotistos is research assistant professor with the Physics Department of the University of Crete, Greece. He obtained his Ph.D. in Physics from Temple University. He has taught and done research in Purdue University's electrical engineering department, Temple University's physics department, and the Physics and Space Sciences Department of the Florida Institute of Technology.

LME 